\title{
MONIULOTTEINEN TUKIPERHETOIMINTA LAPSEN KOKEMANA ${ }^{1}$
}

Tiina Lehto-Lundén: VTT, lehtori, Metropolia Ammattikorkeakoulu

tiina.lehto-lunden@metropolia.fi

Janus vol. 29 (1) 2021, 83-89

Mitä sä haluaisit kertoa mulle siitä, että sä käyt tukiperheessä? Tällaisen kysyvän kutsun osoitin tutkimuksessani mukana oleville lapsille. Se mitä sain vastaukseksi, on kiteytynyt tutkimukseksi ja kertoo meille lasten kokemustiedosta tukiperhetoiminnasta. (LehtoLundén 2020.)

Valitettavan usein, kun halutaan saada tietoa lapsen elämään liittyvistä asioista, pyydetään siitä kertomaan lapsen vanhempia tai muita lapsen ympärillä olevia aikuisasiantuntijoita (Forsberg ym. 2006). Olen tutkimuksessani toiminut toisin. Olen mennyt lasten luo ja kysynyt tukiperhetoiminnasta heiltä itseltään. En ole antanut muiden sanoittaa lasten kokemuksia toiminnasta, jonka asiantuntijoita he itse ovat. Olen halunnut vahvistaa lasten ja nuorten omaa ääntä sekä tehdä näkyväksi heidän ajatuksiaan tuesta, joka kohdistuu heihin itseensä.

Minulle lapsi on aktiivinen, kokemuksellinen ja tiedollinen toimija, jolla on merkittävä rooli tieteellisenkin tiedon muodostumisessa. Lasten osallisuuden vahvistaminen ja lasten tiedon arvostaminen ovat lisääntyneet läpi viime vuosikymmenten, ja lastensuojelun tutkimuksen ja käytännön kentillä on puhuttu jopa lasten ja nuorten osallisuusbuumista (Pekkarinen \& Vehkalahti 2012, 10-11). Siltikään tutki- mukseen perustuva lapsiasiakkaiden kokemustieto ei ainakaan vielä ole noussut vallitsevaksi näkökulmaksi tutkimustoimintaan, eikä se välttämättä aina ohjaa käytännön hyvinvointityötäkään (esim. Kallinen ym. 2018, 15). En usko, että kyse on sosiaalityön ammattilaisten osaamattomuudesta tai tahtomattomuudesta kuulla lapsia, vaan yksinkertaisesti hyvin aikuisvetoisesta kulttuurisesta toimintamallista, jonka purkaminen on edelleen kesken.

Tukiperhetoiminta on yksi niistä monista palveluista, joita lastensuojelu tarjoaa perheiden tueksi vaikeissa ja haastavissa elämäntilanteissa. Erityisesti, jos lapsiperheen omat sosiaaliset verkostot ovat vähäiset tai heikot, on yleistä, että tueksi voidaan tarjota tukiperhetoimintaa. Lapsen käyminen tukiperheessä tarkoittaa konkreettisesti sitä, että lapsi liikkuu säännöllisesti kahden erilaisen kodin välillä. Lapsi asuu pääosin omassa biologisessa perheessään ja matkustaa noin kerran kuukaudessa viikonlopuksi tukiperheeseen. Lapsen näkökulmasta tukiperheen tarvetta on perinteisesti perusteltu esimerkiksi sillä, että se lisää turvallisia ja luotettavia sosiaalisia suhteita sekä sillä, että tukiperhe mahdollistaa lapselle toisenlaisen perhemallin saamisen. (Svenlin 2020; Terveyden ja hyvinvoinnin laitos 2019a.) 
Vaikka tukiperhetoiminta fokusoituu tiiviisti lapseen, on toiminta pitkälti aikuisvetoista. Tarve tukiperheeseen nousee vanhemman jaksamisen näkökulmasta ja myös tukiperheviikonlopuista sopiminen on pitkälti aikuisten välistä, puhumattakaan siitä, ketkä tekevät päätöksiä, kuinka kauan tai usein lapsi tukiperheessä saa käydä. Olisiko jo aika astua aikakaudelle, jossa lapsen tieto nähdään tasa-arvoisena aikuisen tietoon nähden?

Vaikka lastensuojelullisten tukimuotojen piirissä on Terveyden ja hyvinvoinnin laitoksen (2019b) mukaan Suomessa vuosittain lähes 55000 lasta, on lastensuojeluasiakkuudessa olevien lasten ja nuorten kokemuksiin perustuvaa tutkimuksellista tietoa palveluista sekä yksittäisistä tukimuodoista yllättävän vähän. Lasten elämäntilanteisuuden huomioivalle tutkimukselle on yhteiskunnallista tilausta. Tähän tiedon vajeeseen olen tutkimuksellani halunnut tarttua ja vahvistaa laajasti käytetyn tukiperhetoiminnan tutkimusperusteisuutta. Tutkimukseni onkin ensimmäinen, joka tarkastelee lasten kokemuksia tästä tuen muodosta.

Kokemukset ovat kiinnostava tutkimuskenttä. Vaikka kokemus on käsitteenä arkinen, antavat kokemukset yksilöllisyydelle arvon. Tästä itsestään selvästä ihmiselämän osasta on kuitenkin vaikea saada tieteellistä otetta. Kokemus on nykymerkityksessään, elettyä kokemusta tarkoittavana, tarkastelun kohteena melko tuore ilmiö. Kokemuksen käsitekin yleistyi vasta 1800-luvulla korostamaan inhimillisen kokemusmaailman kokonaisvaltaisuutta ja yksilökohtaisuutta. Kokemuksen tutkimus rohkaisee asettumaan elämi- sen keskelle ja ymmärtämään toista ihmistä elämänsä parhaana asiantuntijana. (Gadamer 1981; Kukkola 2018; Tökkäri 2018.)

Päästäkseni lasten kokemusten äärelle tein valinnan kiinnittää tutkimukseni viitekehykseksi ja metodologiseksi ohjenuoraksi eksistentialistisen fenomenologian. En ole filosofi, enkä sellaiseksi asettaudu, vaan korostan inspiroituneeni fenomenologiasta ja soveltavani sitä lasten kokemusten tutkimiseen sosiaalityön asiantuntijana ja erityistieteilijänä.Ymmärrykseni maailmasta sekä ihmisestä ainutlaatuisena ja elämismaailmassaan kokonaisvaltaisena olentona on se ajatuksellinen pohja, johon olen sitoutunut. Fenomenologian käyttö ja muodostamani ihmiskäsitys ovat auttaneet minua pyrkimyksessäni ymmärtämään lasta ja tarkastelemaan hänen kokemuksiaan. Eksistentiaalisuus kiteytyy ymmärryksessäni siihen, että tutkimukseni lähtökohtana on lapsen ainutkertainen elämäntilanne, jossa tukiperhetoiminta on tärkeä elementti lapsen kasvaessa ainutkertaiseksi yksilöksi.

Fenomenologinen tosiasia on se, että ihmisen kokemus, millaisena tahansa, on aina tosi ja aito. Kokemus on aina kokijansa omaa, eikä sitä voi ihminen itse, ei tutkija eikä edes sosiaalityöntekijä epäillä. Kokemukset kuuluvat jokaisen oman mielen ympäristöön ja siksi muut eivät voi niitä vahvistaa, todentaa tai hylätä. Näin ollen toisen ihmisen kokemukset ovat aina osaksi myös saavuttamattomia. (Heidegger 2000; Koivisto ym. 2014.) Suomalaisten fenomenologien Juha Perttulan ja Timo Latomaan (2011) sanoittamana fenomenologinen menetelmä on ra- 
kastavaa ja pakottautuvaa asennoitumista tutkittavaan todellisuuteen. Se on mahdollisuuden antamista ihmetyksen tunteelle ja tietoista ponnistelua niin, että ihmisen todellisuuden ymmärtäminen saa tilaisuuden toteutua.

Miten mennä kohti, mutta pysyä silti ulkopuolisena ja tiedostaa, ettei toisen ihmisen kokemuksia voi ymmärtää kuin henkilö itse? Lasten kokemustiedon äärelle pääseminen vaatikin aineistonkeruun tarkkaa pohdintaa. Tutkimukseni lapset ovat halutessaan olleet aktiivisia osapuolia tutkimustapaamisissa. He eivät ole olleet kanssatutkijoita, mutta eivät myöskään vain tutkimuksen kohteita. Koska tutkimustani ohjasi myös kiinnostus siitä, miten lasten kokemuksia voi kerätä, suunnittelin monimuotoisen, viisivaiheisen aineiston keruutavan. Siihen kuului haastattelutapaamisia lapsen kotona sekä tukiperheessä, lapsen tukiperheeseen suuntautuva matka, jossa olin mukana, sekä lapsen toimiminen dokumentaristina tukiperheessään. Lapset kertoivat kokemuksistaan haastatteluissa ja lisäksi heillä oli mahdollisuus valokuvata ja videoida sekä piirtää kokemuksistaan. Lapsia oli mukana tutkimuksessani 11 ja he olivat aineiston keruun aikana 3-15-vuotiaita.

Valintojeni lähtökohtana on ollut se, että lapsille muodostuu sekä fyysisesti että emotionaalisesti turvallinen tila jakaa kokemuksiaan. Aineistoni keruu on tapahtunut eräänlaisena hitaana metodina, jossa olen askelittain edennyt yhdessä lapsen kanssa. Erityisenä fenomenologisena piirteenä aineistonkeruuta on ohjannut avoin ja ihmettelevä asenteeni.
Lasten kokemusten fenomenologinen analyysi paljasti monimuotoisen kuvan tukiperhetoiminnasta. Tukiperhetoiminta merkityksellistyy lasten kokemuksissa kokonaisuudeksi, joka kiteytyy suhteiksi, toimintaympäristöksi, toiminnallisuudeksi sekä kahden kodin välillä kulkemiseksi. Kaikkien näiden elementtien merkitys vahvistuu, mitä pidemmän aikaa lapset ovat tukiperheessä käyneet.

Tukiperheeseen lähteminen ja matka aloittavat lapsen kokemuksissa tukiperheviikonlopun. Siihen liittyvät tiiviisti omien tavaroiden pakkaaminen ja odotus sekä matkustaminen. Tukiperhetoiminta konkreettisesti liikuttaa lasta kahden kodin välillä ja aina kokemus ei ole lapselle pelkästään mielekäs. Lähtö tukiperheeseen voi esimerkiksi katkaista lapsen omat suunnitelmat tai lasta saattaa kuormittaa epätietoisuus tilanteessa, jossa hän ei tiedä, milloin on itseasiassa seuraavan kerran menossa tukiperheeseen.

Lapset kokevat tukiperhetoiminnan myös suhteena, joka tarkoittaa suhteen luomista tukiperheeseen, kohtaamisia ja jatkuvuutta. Arkea eletään omassa perheessä, tukiperheeseen mennään viettämään vapaa-aikaa. Vaikka nähtävissä on, että tukiperheessä vietettyihin viikonloppuihin muodostuu oma arkinen rytminsä, on se kuitenkin irrallaan siitä arjesta, jota omassa kodissa rytmittävät päiväkodissa ja koulussa käyminen. Lapset muodostavat suhteita laajasti tukiperheessä oleviin perheenjäseniin. Tukiperheestä muodostuukin lapselle eräänlainen suhteiden verkosto. Erityisesti lasten kokemuksissa korostuivat suhteet bonussisaruksiin ja muihin oman ikäisiin lapsiin, joita tukiper- 
heessä tavattiin. Myös tukiperheeseen liittyvä lemmikki voi merkityksellisyydessään vertautua ihmissuhteeseen.

Lasten kokemuksissa tukiperhetoiminnan tunnusmerkkinä on ennen kaikkea yhdessä tekeminen. Se kiteytyy toiminnallisuudeksi eli konkreettiseksi tekemiseksi ja erilaisiksi tapahtumiksi, joita tukiperheen perheenjäsenten kanssa tehdään. Lapset painottivat tekemisten kautta myös oman kodin ja tukiperheen erilaisuuksia. Tukiperheet olivat mahdollistaneet lapsille toiminnan muotoja, joita he eivät olleet koskaan kotona olleessaan saaneet kokea.

Tukiperhetoiminta tuo lapsen elämään uusien ihmisten lisäksi uuden paikan ja siellä olevat kodin tavarat ja lelut, joihin lapsen toivotaan kiinnittyvän.Ympäristön vaihtaminen ja uusi paikka ovatkin olennainen osa tukiperhetoimintaa. Paikat eivät ole vain neutraaleja materiaalisia maailmoja, vaan ne ovat lapsille merkityksellisiä ja kokemuksellisia toimintakenttiä. Paikkatunteen syntyminen vie pitkän aikaa, ja sitä kasvattavat rutiininomaiset tekemiset ja toiminnot, arkipäivän kokemukset sekä merkittävimmät elämän tapahtumat (Jack 2010). Lasten kokemukset osoittivatkin, että lapselle voi syntyä kiintymyssuhde tukiperheen toimintaympäristöön siellä olevien ihmisten lisäksi. On huomioitavaa myös se, että sosiaalityö ja lastensuojelu omilla palveluillaan ja toiminnoillaan ovat osaltaan luomassa näitä erilaisia paikkoja lasten elämään.

Tukiperhetoiminta on yksi sosiaalityön väline ja pohjautuu vahvasti ajatukselle toimivasta ihmissuhteesta. Johtopäätöksenä voin todeta, että toimivat ja vuorovaikutteiset ihmissuhteet tuki- perheen perheenjäseniin ovat oleellisia, mutta ne ovat vain yksi osa tukiperhetoimintaa, sen toimivuutta tai toimimattomuutta. Sekä sosiaalityön ammatillisessa että tieteellisessä keskustelussa on kiinnitetty vain vähän huomiota siihen, miten paikkakiintymys vaikuttaa lapsen kehitykseen ja hyvinvointiin, vaikka paikkoihin kiinnittymisen tärkeys lasten hyvinvoinnille, kehitykselle ja identiteetille on osoitettu (Jack 2015; Morgan 2010; Ritala-Koskinen 2018). Vaikka lasten kokemuksissa tuli esiin myös negatiivisia ja ei niin miellyttäviä asioita tukiperhetoiminnasta, tutkimukseni vahvistaa, että tukiperhetoiminta voi tarjota lapsen elämään kannattelevia toimintamalleja ja luoda lapsille positiivisia muistikuvia ja tunne-elämyksiä, jotka parhaassa tapauksessa tukevat lasta aikuiselämään asti. Näiden kannattelevien toimintamallien rakentuminen tarvitsee kuitenkin aikaa ja siksi merkittävää on, että tukiperhesuhteella on pitkäkestoinen ajallinen jatkumo, jos toiminnalla halutaan vahvistaa erityisesti suhdeperusteisuutta tai lapsen kiintymystä paikkaan.

Koska olen toiminut myös tukiperhetoiminnan sosiaalityöntekijänä, tiedän, että tukiperhetoimintaa pitkälti esitellään lapsille tulevan tukiperheen kodin ympäristön ja esimerkiksi siellä olevien lemmikkien kautta. Tarjotaan elementtejä lapsen paikkakiintymykselle, mutta oletusarvoisesti kuitenkin toivotaan, että lapsi kiinnittyy ja luo suhteen ensisijaisesti tukiperheessä oleviin ihmisiin, vaikkei tukiperheen perheenjäsenistä persoonina kerrotakaan oikeastaan mitään. Tällainen toiminta on hieman ristiriitaista suhdeperusteisiin tavoitteisiin nähden. Toivonkin sosiaalityön ammattilaisten pohtivan, mitä ja miten 
tukiperheistä lapsille kerrotaan. Olisitko sinä valmis aloittamaan yökyläilyn perheessä, josta tiedät vain perheenjäsenten ja lemmikkien märän tai sen, että onko perheellä omaa pihaa?

Lisäksi tutkimukseni osoittaa, että moninaisten osallistavien menetelmien käyttö tutkimustapaamisissa ja myös asiakastapaamisissa lasten kanssa on kannattavaa, koska niiden avulla voidaan tasoittaa valta-asetelmaa aikuisen ja lapsen välillä. Erityisesti lasten kutsuminen valokuvaamaan ja videoimaan tutkimukseni aineistonkeruuprosessiin on antanut valtaa lasten käsiin. Rohkaisenkin kentällä olevia lasten kanssa toimivia ammattilaisia kutsumaan lapsia dokumentoimaan elämäänsä ja tarjoavan monipuolisia menetelmiä lapsille ajatustensa kertomiseen. Menetelmien käyttö ei kuitenkaan saa olla itseisarvo, vaan mahdollisuus, jossa jälleen huomioidaan lasten yksilöllisyys.

Näkemykseni mukaan fenomenologinen metodi voi vahvistaa sosiaalityön asiakasnäkökulmaa, vaikka toisaalta sen haasteena onkin äärimmäinen avoimuus. Fenomenologiassa painotetaan, että toisia ihmisiä ei kohdata siten, että oma subjekti on ensisijaisesti esillä (Heidegger 2000). Fenomenologiaan pohjautuva kokemuksen tutkimus on syvästi ihmistä ja inhimillisyyttä ymmärtävää ja avaavaa, täydentää toiseuden ymmärtämistä ja sietämistä sekä parantaa ihmisten keskinäisen kanssakäymisen mahdollisuuksia (Tökkäri 2015, 172). Se on tiiviisti sosiaalityön eetokseen asettuvaa.

Olen fenomenologian avulla aktiivisesti pyrkinyt pois luontaisestakin tarpeesta tulkinnallisuuteen. Eksistentiaalisesta näkökulmasta jo tulkitsijan ensiaskeleet vievät poispäin itse asiasta ja johtavat vaäjäämättä kokemusten ohi. Tulkinnat kuljettavat tutkijan vain itseensä, eivät kohti toista. (Perttula 2010.) Rohkenen sanoa, että myös sosiaalityössä olisi enemmän tarvetta asiakkaiden kuulemiselle ja ymmärtämiselle kuin eletyn elämän tulkitsemiselle.

Kuunneltuani lasten kokemuksia haluan esittää toiveen, että tukiperhetoimintaa koordinoivat ammattilaiset huomioisivat entistä paremmin lasten yksilöllisyyden sekä lasten tarpeiden moninaisuuden palvelua kehitettäessä. Lasten eli palvelun käyttäjien näkökulmasta kaivataan selvästi ketteryyttä palvelun toteuttamiseen. Vaikka lasten asema tukiperheprosessissa on vuosien saatossa vahvistunut, osoitti kokemusten tarkastelu, että toiminta on edelleen vahvasti aikuisten hallinnassa. Päsääntöisesti lapsen tarpeita määrittelevät tukiperhetoiminnassa aikuiset ja erityisesti palvelun jatkuvuus on lähes yksinomaan aikuisten päätösvallassa. Tukiperheessä käyvä lapsi ei saisi olla vain toiminnan irrallinen tai ulkopuolinen kohde. Lähetänkin arkailemattoman toiveen, että tukiperhetoiminnan aikuisvetoisuutta tulee purkaa.

Tarkoituksenani ei ole antaa vastuuta lapselle tukiperhetoiminnasta, mutta haluan osoittaa lapsen subjektiuden osana monitahoista kokonaisuutta. Kyse on siitä, että lapsen mielipiteellä ja kokemuksella on merkitystä ja että aikuisten on aktiivisesti rohkaistava lasta kertomaan ajatuksiaan myös toimimattomista asioista. Sekä tukiperhetoimintaan sekä lastensuojelun muihin palveluihin liittyvää tutkimusta tulee jatkaa. Vaikka lastensuojelun tutkimus- 
ta on nykyään jo runsaasti ja sen asema on vahvistunut, tutkimustieto on edelleen pienimuotoista, pistemäistä ja hajallaan, kuten tutkimusprofessori Tarja Heino (2017) on todennut. Olisi tärkeää tarkastella esimerkiksi tukiperhetoiminnan vaikuttavuutta. Lisäksi yhtenä jatkotutkimusaiheena toivoisin tartuttavan myös tukiperheessä asuvien lasten, niin kutsuttujen bonussisarusten näkökulmaan.

Tutkimukseni todentaa sen, että lapsilta on rohkeasti kysyttävä ja heidän luokseen on mentävä. Siksi on tärkeää palauttaa saamani tieto myös lapsille itselleen. Toivon tavoittavani kaikki tutkimuksessani mukana olleet lapset, jotta voin tutkimukseni heille toimittaa. Ei ole epäilystäkään, etteikö lapsi kykenisi täysin relevantisti omalla tavallaan ilmaisemaan kokemuksiaan ja ajatuksiaan. Meidän on vain kiinnostuttava, kysyttävä ja kuunneltava.

\section{VIITE}

1 Puheenvuoro on Helsingin yliopistossa 6.6.2020 tarkastetun sosiaalityön väitöskirjan lectio praecursoria.

\section{KirJallisuUs}

Forsberg, Hannele \& Ritala-Koskinen, Aino \& Törrönen, Maritta (2006) Kohti lapsisensitiivistä sosiaalityötä. Teoksessa Hannele Forsberg, Aino Ritala-Koskinen \& Maritta Törrönen (toim.) Lapset ja sosiaalityö: kohtaamisia, menetelmiä ja tiedon uudelleenarviointia. Helsinki: PSkustannus, 5-20.

Gadamer, Hans-Georg (1981) Truth and method. London: Sheed \& Ward.

Heidegger, Martin (2000) Oleminen ja aika. Suomentanut Reijo Kupiainen.
Saksankielinen alkuteos Sein und Zeit 1927. Tampere:Vastapaino.

Heino, Tarja (2017) Kamppailu lastensuojelututkimuksen paikasta ja puitteista. Teoksessa Rosi Enroos, Mikko Mäntysaari \& Satu Ranta-Tyrkkö (toim.) Mielekäs tutkimus. Näkökulmia sosiaalityön tutkimuksen missioihin. Tampere: Tampere University Press, 193-226.

Jack, Gordon (2010) Place matters: The significance of place attachments for children's well-being. British Journal of Social Work 40 (3), 755-771. https:// doi.org/10.1093/bjsw/bcn142

Jack, Gordon (2015) 'I may not know who I am, but I know where I am from'. The meaning of place in social work with children and families. Child and Family Social Work 20 (4), 415-423. https:// doi.org/10.1111/cfs.12091

Kallinen, Kati \& Laitinen, Merja \& Lantela, Lauri \& Leinonen, Jaana \& Nikupeteri, Anna \& Nurmi, Henna \& Turunen, Tuija (2018) Lasten, nuorten ja perheiden osallisuus monitoimijaisen yhteistyön mahdollisuuksina ja haasteina. Teoksessa Päivi Petrelius \& Pia Eriksson (toim.) Uudistuva lastensuojelu - kohti asiakkaiden ja ammattilaisten yhteistoimintaa. Työpaperi 32. Helsinki: Terveyden ja hyvinvoinnin laitos, 14-23.

Koivisto, Kaisa \& Kukkola, Jani \& Latomaa, Timo \& Sandelin, Pirkko (2014) Kokemuksen mahdollisuudet. Teoksessa Kaisa Koivisto, Jani Kukkola, Timo Latomaa \& Pirkko Sandelin (toim.) Kokemuksen tutkimus IV: annan kokemukselle mahdollisuuden. Rovaniemi: Lapin yliopistokustannus, 7-27.

Kukkola, Jani (2018) Kokemuksen tutkimuksen metatiede: kokemuksen käsitteen käytön ja kokemuksen ehtojen tutkimus. Teoksessa Jarkko Toikkanen \& Ira A.Virtanen (toim.) Kokemuksen tutkimus VI. Kokemuksen käsite ja käyttö. Rovaniemi: Lapin yliopistokustannus, 41-63.

Lehto-Lundén, Tiina (2020) Lapsi tukiperheessä. Eksistentiaalis-fenomenologinen tutkimus lasten kokemuksista. Heikki Waris -instituutin tutkimuksia 3. Helsinki: Pääkaupunkiseudun osaamiskeskus Socca.

Morgan, Paul (2010) Towards developmen- 
tal theory of place attachment. Journal of Environmental Psychology 30 (1), 11-22. https://doi.org/10.1016/j.jenvp.2009.07.001

Pekkarinen, Elina \& Vehkalahti, Kaisa (2012) Johdanto. Instituutiot lapsuutta ja nuoruutta rakentamassa - lapset ja nuoret instituutioita uudistamassa. Teoksessa Elina Pekkarinen, Kaisa Vehkalahti \& Sami Myllyniemi (toim.) Lapset ja nuoret instituutioiden kehyksissä. Nuorten elinolot -vuosikirja 2012. Nuorisotutkimusverkoston julkaisuja 131. Helsinki: Terveyden ja hyvinvoinnin laitos, 9-21.

Perttula, Juha (2010) Eksistentiaalisen elämyspedagogiikan luonto ja teot. Teoksessa Timo Latomaa \& Seppo J.A. Karppinen (toim.) Seikkaillen elämyksiä II. Elämyksen käsitehistoriaa ja käytäntöjä. Rovaniemi: Lapin yliopistokustannus, 58-81.

Perttula, Juha \& Latomaa, Timo (2011) Saatteeksi. Teoksessa Juha Perttula \& Timo Latomaa (toim.) Kokemuksen tutkimus. Merkitys - tulkinta - ymmärtäminen. 4. painos. Rovaniemi: Lapin yliopistokustannus, 9-16.

Ritala-Koskinen, Aino (2018) Avohuollon asiakaslasten asumisliikkuvuus. Teoksessa Hannele Forsberg \& Aino Ritala-Koskinen (toim.) Monen kodin lapset. Helsinki: Gaudeamus, 77-102.
Svenlin, Anu-Riina (2020) Kannatteleva ja jännitteinen tukiperhetoiminta. Lastensuojelun tukiperhetoiminnan käyttöteoria ja tukisuhteet. JUY Dissertations 180. Jyväskylä: Jyväskylän yliopisto.

Terveyden ja hyvinvoinnin laitos (2019a) Tukihenkilöt ja -perheet. https://www. thl.fi/fi/web/lapset-nuoret-ja-perheet/ peruspalvelut/sosiaalipalvelut/tukihenkilot-ja-perheet. Luettu 5.12.2019.

Terveyden ja hyvinvoinnin laitos (2019b) Lastensuojelu 2018. Barnskydd 2018. Child welfare 2018. Tilastoraportti 23, 4.6.2019. http://urn.fi/URN:NBN:fife2019060418326. Luettu 5.12.2019.

Tökkäri, Virpi (2015) Monitieteistä kokemuksen tutkimusta Lauri Rauhalan jalanjäljissä.Teoksessa Virpi Tökkäri (toim.) Kokemuksen tutkimus V. Lauri Rauhala 100 vuotta. Rovaniemi: Lapin yliopistokustannus, 151-186.

Tökkäri, Virpi (2018) Fenomenologisen, hermeneuttis-fenomenologisen ja narratiivisen kokemuksen tutkimuksen käytäntöjä. Teoksessa Jarkko Toikkanen \& Ira A. Virtanen (toim.) Kokemuksen tutkimus VI. Kokemuksen käsite ja käyttö. Rovaniemi: Lapin yliopistokustannus, 64-84. 